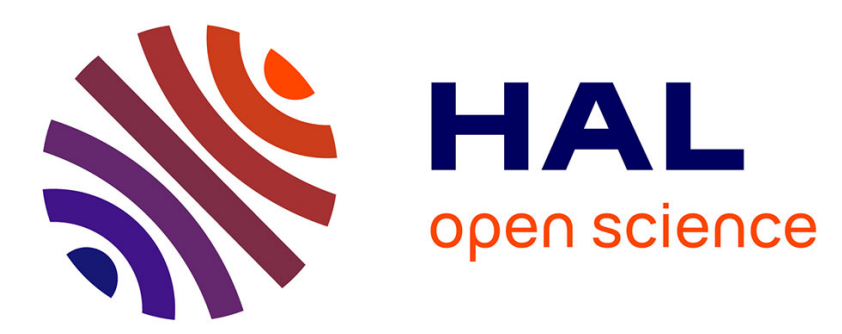

\title{
DMSO-PdI2 as a powerful oxidizing couple of alkynes into benzils: one-pot synthesis of nitrogen-containing five- or six-membered heterocycles
}

Céline Mousset, Olivier Provot, Abdallah Hamze, Jérôme Bignon, Jean-Daniel Brion, Mouâd Alami

\section{To cite this version:}

Céline Mousset, Olivier Provot, Abdallah Hamze, Jérôme Bignon, Jean-Daniel Brion, et al.. DMSO-PdI2 as a powerful oxidizing couple of alkynes into benzils: one-pot synthesis of nitrogen-containing five- or six-membered heterocycles. Tetrahedron, 2008, 64 (19), pp.4287-4294. 10.1016/j.tet.2008.02.081 . hal-02394600

\section{HAL Id: hal-02394600 \\ https://hal.science/hal-02394600}

Submitted on 4 Dec 2019

HAL is a multi-disciplinary open access archive for the deposit and dissemination of scientific research documents, whether they are published or not. The documents may come from teaching and research institutions in France or abroad, or from public or private research centers.
L'archive ouverte pluridisciplinaire HAL, est destinée au dépôt et à la diffusion de documents scientifiques de niveau recherche, publiés ou non, émanant des établissements d'enseignement et de recherche français ou étrangers, des laboratoires publics ou privés. 


\section{DMSO-PdI2 as a powerful oxidizing couple of alkynes into benzils: one-pot synthesis of nitrogen-containing five- or six-membered heterocycles}

Céline Mousset, Olivier Provot, Abdallah Hamze, Jérôme Bignon, Jean-Daniel Brion, Mouad Alami

\section{To cite this version:}

Céline Mousset, Olivier Provot, Abdallah Hamze, Jérôme Bignon, Jean-Daniel Brion, et al.. DMSO-PdI2 as a powerful oxidizing couple of alkynes into benzils: one-pot synthesis of nitrogencontaining five- or six-membered heterocycles. Tetrahedron, Elsevier, 2008, 64 (19), pp.4287-4294. 10.1016/j.tet.2008.02.081 . hal-02394600

\section{HAL Id: hal-02394600 \\ https://hal.archives-ouvertes.fr/hal-02394600}

Submitted on 4 Dec 2019

HAL is a multi-disciplinary open access archive for the deposit and dissemination of scientific research documents, whether they are published or not. The documents may come from teaching and research institutions in France or abroad, or from public or private research centers.
L'archive ouverte pluridisciplinaire HAL, est destinée au dépôt et à la diffusion de documents scientifiques de niveau recherche, publiés ou non, émanant des établissements d'enseignement et de recherche français ou étrangers, des laboratoires publics ou privés. 


\title{
DMSO-PdI 2 as a powerful oxidizing couple of alkynes into benzils: One-pot synthesis of nitrogen-containing 5- or 6- membred heterocycles
}

\author{
Céline Mousset, ${ }^{\mathrm{a}}$ Olivier Provot, ${ }^{* a}$ Abdallah Hamze, ${ }^{\mathrm{a}}{ }^{\mathrm{a}}$ érôme Bignon, ${ }^{\mathrm{b}}$ Jean-Daniel Brion ${ }^{\mathrm{a}}$ and \\ Mouâd Alami*a \\ ${ }^{a}$ Univ Paris-Sud, CNRS, BioCIS, UMR 8076, Laboratoire de Chimie Thérapeutique, Faculté de Pharmacie, rue J.B. Clément F-92296 \\ Châtenay-Malabry, France. ${ }^{b}$ Institut de Chimie des Substances Naturelles, CNRS, avenue de la Terrasse, F- 91198 Gif sur Yvette, France.
}

\begin{abstract}
PdI}_{2}$ in DMSO promoted the oxidation of functionalized diarylalkynes into benzil derivatives in excellent yields. This new oxidation reaction was achieved with short reaction times and low loading of palladium catalyst .This efficient catalytic process has been applied successfully to the one-pot construction of a series of nitrogen-containing heterocycles of biological interest according to a tandem oxidation-nitrogen nucleophiles condensation-cyclization.
\end{abstract}

\section{Introduction}

In the manufacture of pharmaceutical targets, increasing attention is now being paid to simplification and improvement of the existing methods. The oxidation of substituted diarylalkynes, readily accessible via Sonogashira-Linstrumelle (S-L) coupling, ${ }^{1}$ constitutes one of the most versatile processes in organic chemistry for the synthesis of benzils. ${ }^{2}$ The latter have received a great deal of attention because of their properties and as useful synthetic intermediates in the preparation of various heterocyclic compounds of biological interest ${ }^{3}$ including, imidazoles or quinoxalines. The oxidation reaction has been widely explored using various oxidants systems such as, $\mathrm{KMnO}_{4},{ }^{4} \quad \mathrm{SO}_{3} /$ dioxane, ${ }^{5} \quad \mathrm{H}_{5} \mathrm{IO}_{6},{ }^{6}$ $\mathrm{Co}(\mathrm{OAc})_{2} / \mathrm{Mn}(\mathrm{OAc})_{2} / \mathrm{NaBr},{ }^{7}$ or $\mathrm{H}_{2} \mathrm{O}_{2} / \mathrm{Fe}(\mathrm{PA})_{2}{ }^{8}$ (bis(picolinato)iron(II)). Though all these transformations are suitable methods with a range of simple diarylalkynes, many of them display low chemoselectivity and provide low yields with substrates having sensitive functionalities. During the last decade, DMSO has been successfully used as an oxidant either in the presence of $\mathrm{CH}_{3} \mathrm{SO}_{3} \mathrm{H} / \mathrm{HCO}_{2} \mathrm{H} / \mathrm{HBr}^{9}$ mixture or $\mathrm{PdCl}_{2}{ }^{10}$. Typically in the latter case, the reaction is reported to require high loading of catalyst $(10 \mathrm{~mol} \%)$ and long reaction times, sometimes extending into days that can seriously affect the yield and the outcome of the oxidation reaction, particularly with substrates having strong electronwithdrawing groups ${ }^{5,11}$ (e.g.; $\mathrm{CN}, \mathrm{NO}_{2}$ ) or an ortho substituent. ${ }^{12}$ Additionally, the oxidation reaction is far from trivial with substrates containing a heteroaryl nucleus including for instance a pyridine or a pyrazole. $^{10,13}$ Therefore, alternative routes and more reliable procedures for the synthesis of benzils are welcome. The remaining challenge is to obtain highly substituted benzils from functionalized diarylalkynes without compromising reagent safety, simplicity and practicality.

Recently, we reported the DMSO-oxidation of functionalized diarylalkynes in the presence of various transition metal salts. ${ }^{14}$ We have found that the better results were obtained using a catalytic amount (10 mol\%) of environmentally friendly $\mathrm{FeBr}_{3}$ or $\mathrm{FeBr}_{3} / \mathrm{TfOH}$ combination that act as Lewis acids to activate the triple bond, and further allowing successive additions of DMSO. However, during this study we noticed that substrates having a free phenolic function or a cyano group, for instance, were resistant to the oxidation reaction, and gave in best cases the corresponding benzils with moderate to low yields.

In an ongoing medicinal chemistry program towards the synthesis of substituted heterocyclic compounds, ${ }^{15}$ we required a more reliable and chemoselective procedure for the synthesis of several benzils that could be used in situ as intermediates for the elaboration of the desired target molecules. The procedure should be environmentally benign and not involve the use of highly toxic and

\footnotetext{
"Keywords : Benzils; Palladium; DMSO; alkynes; oxidation;.tandem reactions; heterocyclic compounds

*Corresponding authors: (O.P.) tel.: +33 14683 5847; fax: +33 14683 5828; olivier.provot@u-psud.fr (M.A.) tel.: +33 14683 5887; fax: +33 14683 5828; mouad.alami@u-psud.fr
} 
hazardous reagents. To this end, we explored the use of $\mathrm{PdI}_{2}$ as a catalyst for the oxidation of diarylalkynes with DMSO with the hope that its best Lewis acid character in comparison with $\mathrm{PdCl}_{2}$, would confer to the $\mathrm{Pd}(\mathrm{II})$ catalyst a better catalytic activity, thus reducing the reaction times and the quantity of catalyst. Herein, we report the results of this study and disclose that catalytic $\mathrm{PdI}_{2}$ in DMSO can be conveniently combined with the condensation reaction of various nitrogen-nucleophiles with benzil intermediates to prepare efficiently in a onepot procedure nitrogen-containing heterocycles.

\section{Results and discussion}

At first, the oxidation reaction in DMSO was studied with the model substrate 1a bearing a $p$ - $\mathrm{CN}$ group which is usually resistant to oxidation. ${ }^{14}$ The results summarized in Table 1 describe the effects of various palladium salts catalysts, additives and temperature on the outcome of this reaction.

To evaluate the efficiency of $\mathrm{Pd}(\mathrm{II})$ salts catalysts, first attempts were carried out by using the same reaction parameters $\left(140{ }^{\circ} \mathrm{C}\right.$, catalyst: $\left.10 \mathrm{~mol} \%\right)$ as we previously described in the alkyne activation by iron bromide. ${ }^{14} \mathrm{We}$ were pleased to observed that $\mathrm{PdBr}_{2}(10 \mathrm{~mol} \%)$ efficiently catalyzed the oxidation of $1 \mathrm{a}$ within $2.5 \mathrm{~h}$ in an excellent isolated yield and no hydrolyzed by-products could be detected (entry 1). In order to increase the Lewis acidity of the Pd(II) catalyst, the next experiment was achieved by adding $\mathrm{TfOH}(20 \mathrm{~mol} \%)$ to $\mathrm{PdBr}_{2}$. Accordingly, the oxidation occurred within only 25 min and $\mathbf{2 a}$ was formed in $92 \%$ yield (entry 2). Similar experiments were achieved by changing $\mathrm{PdBr}_{2}$ to $\mathrm{PdI}_{2}$. We found that $\mathrm{PdI}_{2}$ proves to be a more efficient catalyst to oxidize 1a even without the additional help of TfOH (entries 3 and 4). Next, the effect of the temperature was investigated. At a lower temperature $\left(100{ }^{\circ} \mathrm{C}\right.$; entry 5$)$, total disappearance of the starting alkyne 1a was observed but after a prolonged reaction time (entry $5,2 \mathrm{~h}$ ). We then decided to determine at $140{ }^{\circ} \mathrm{C}$ the useful amount of $\mathrm{PdI}_{2}$ to properly carry out this oxidation in a reasonable time. Results described in entries 6-8 clearly showed that the quantity of catalyst could be decreased to $2 \mathrm{~mol} \%$ without loss of efficiency, whereas a longer reaction time was required when using only $1 \mathrm{~mol} \%$ of $\mathrm{PdI}_{2}$. The supremacy of $\mathrm{PdI}_{2}$ towards $\mathrm{PdCl}_{2}$ was clearly demonstrated in term of shortened reaction time and efficiency by the next attempts. Thus, replacing $\mathrm{PdI}_{2}$ by $\mathrm{PdCl}_{2}\left(2 \mathrm{~mol} \%, 1 \mathrm{~h}, 140{ }^{\circ} \mathrm{C}\right)$ induced a lowering of the conversion rate and gave $\mathbf{2 a}$ in only $38 \%$ yield (entry 9). In this case, as shown in entry $10,8 \mathrm{~h}$ were required to observe total conversion of 1a, and 2a was isolated in only $59 \%$ yield.

Table 1. Oxidation of diarylalkyne 1a to benzil 2a

\begin{tabular}{lllll} 
& & \\
\hline
\end{tabular}

${ }^{a}$ Isolated yield.

With optimized conditions in hand, we subsequently explored the scope of this reaction with a series of substrates, well-known to be resistant to the oxidation reaction. As summarized in Table 2, various diarylalkynes undergo efficiently the oxidation reaction with the catalytic system $\mathrm{PdI}_{2} / \mathrm{DMSO}$. The representative examples in Table 2, illustrate the generality of this reaction. Diarylalkynes $\mathbf{1 b}$ and $\mathbf{1 c}$, containing electronwithdrawing groups, were oxidized respectively in 3 and $5 \mathrm{~h}$ to the corresponding benzil derivatives in excellent isolated yields (entries 2 and 3). When substrate 1d containing a free phenolic group was treated under these conditions, we were pleased to observe that the expected $p$-OH-substituted benzil 2d was obtained in a good yield and in a reasonable reaction time (entry 4). However, with alkyne 1e having a free amino function, the reaction turned out to be less effective even if other palladium salts sources were used (entry 5) and gave a complex mixture of non-identified by-products. Fortunately, this limitation could be circumvented by decreasing the nucleophily of the nitrogen atom as we observed with an acetamide function (entry 6,93\%). Results depicted in entries 7 and 8 clearly showed that switching the substituent's position on the aromatic from para to ortho did not affect the yield of the reaction but a prolonged reaction time was required for the oxidation of the more hindered aromatic ring.

Table 2. $\mathrm{PdI}_{2}$ mediated oxidation of alkynes $\mathbf{1}$ into benzil derivatives $\mathbf{2}$ in DMSO

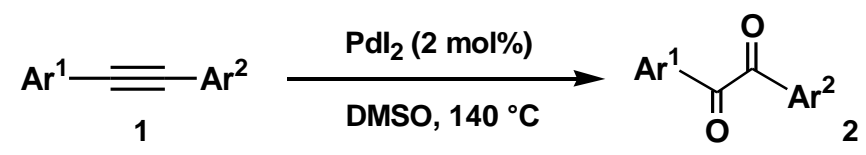




\begin{tabular}{|c|c|c|c|c|c|c|}
\hline Entry & Akynes 1 & & Benzils 2 & & Time (h) & Yield $^{\mathrm{a}}(\%)$ \\
\hline 1 & & $1 \mathbf{a}$ & & $2 a$ & 1 & 91 \\
\hline 2 & & $1 b$ & & $2 b$ & 3 & $96^{\mathrm{b}}$ \\
\hline 3 & & $1 c$ & & $2 c$ & 5 & $93^{c}$ \\
\hline 4 & & 1d & & $2 d$ & 4 & 84 \\
\hline 5 & & $1 e$ & & $2 e$ & - & 0 \\
\hline 6 & & 1f & & $2 f$ & 3 & 93 \\
\hline 7 & & $1 \mathrm{~g}$ & & $2 \mathrm{~g}$ & 2 & $98^{d}$ \\
\hline 8 & & $1 \mathrm{~h}$ & & $2 h$ & 8 & 96 \\
\hline 9 & & $1 \mathbf{i}$ & & $2 \mathbf{i}$ & 6 & 90 \\
\hline 10 & & $\mathbf{1 j}$ & & $2 j$ & 9 & $62^{\mathrm{e}}$ \\
\hline 11 & & $1 \mathrm{k}$ & & $2 k$ & 9 & 57 \\
\hline 12 & & 11 & & 21 & 2 & $90^{\mathrm{f}}$ \\
\hline 13 & & $1 \mathrm{~m}$ & & $2 m$ & 1.5 & 58 \\
\hline
\end{tabular}

${ }^{a}$ Isolated yield. All new compounds exhibited satisfactory spectral properties and microanalyses.

${ }^{b}$ Using $\mathrm{PdCl}_{2}(10 \mathrm{~mol} \%)$ instead of $\mathrm{PdI}_{2}$ (2 mol\%), 2b was obtained within $12 \mathrm{~h}$ in only $60 \%$ yield.

${ }^{c}$ Using $\mathrm{PdCl}_{2}(10 \mathrm{~mol} \%)$ instead of $\mathrm{PdI}_{2}(2 \mathrm{~mol} \%)$, $2 \mathbf{c}$ was obtained in only $68 \%$ yield; see ref. $12 \mathrm{~b}$.

${ }^{d}$ No oxidation occurred when using $\mathrm{PdCl}_{2}(10 \mathrm{~mol} \%)$ instead of $\mathrm{PdI}_{2}(2 \mathrm{~mol} \%)$; see ref. $12 \mathrm{~b}$.

${ }^{e} \mathrm{~A} 26 \%$ yield of $\mathbf{2} \mathbf{j}$ were obtained in the presence of $\mathrm{PdCl}_{2}(10 \mathrm{~mol} \%)$.

${ }^{f} \mathrm{~A} 45 \%$ yield of $\mathbf{2 l}$ were obtained in the presence of $\mathrm{PdCl}_{2}(10 \mathrm{~mol} \%)$.

Table 3. Tandem oxidation-nitrogen nucleophiles condensation-cyclization: One-pot synthesis of heterocycles 3 


\begin{tabular}{|c|c|c|c|c|c|c|c|}
\hline Entry & Akynes 1 & & $\begin{array}{c}\text { Nitrogen- } \\
\text { nucleophile }\end{array}$ & Heterocycles $\mathbf{3}$ & & $\begin{array}{c}\text { Time (h) } \\
1 \rightarrow[2] \rightarrow 3\end{array}$ & $\begin{array}{c}\text { Yield }^{\mathrm{a}} \\
(\%)\end{array}$ \\
\hline 1 & & 1n & & & $3 \mathbf{a}$ & $2+3$ & 82 \\
\hline 2 & & $1 \mathrm{~g}$ & & & $3 \mathbf{b}$ & $2+6$ & 80 \\
\hline 3 & & $1 \mathrm{~g}$ & & & $3 c$ & $2+8$ & 77 \\
\hline 4 & & 1n & & & 3d & $2+3$ & 88 \\
\hline 5 & & 10 & & & $3 \mathbf{e}$ & $2+2$ & 97 \\
\hline 6 & & $1 n$ & & & $3 f$ & $2+10$ & 96 \\
\hline 7 & & $1 \mathbf{p}$ & & & $3 g$ & $2+2$ & 90 \\
\hline 8 & $\|$ & & & & $3 \mathbf{h}$ & $2+1$ & 88 \\
\hline
\end{tabular}

${ }^{a}$ Isolated yield. All compounds exhibited satisfactory spectral properties and analyses.

The efficiency of the $\mathrm{PdI}_{2} / \mathrm{DMSO}$ system was also demonstrated with alkyne 1i having two carbon-carbon triple bond as it proved to be a suitable substrate for this oxidation reaction affording $\mathbf{2} \mathbf{i}$ in an excellent yield $(95 \%$ per triple bond, entry 9). In the following examples, it is interesting to note that the reaction conditions were successfully applied to a series of alkynes having a heteroaromatic nucleus without any difficulty. Thus, replacing a phenyl ring by a 2-pyridyl substituent, the procedure was still efficient and furnished the corresponding benzil $\mathbf{2} \mathbf{j}$ in a satisfactory isolated yield and a reasonable reaction time (entry 10 ). The catalytic activity of $\mathrm{PdI}_{2}$ proved to be superior to $\mathrm{PdCl}_{2}$, as the use of $\mathrm{PdCl}_{2}$ induced a lowering of the conversion rate and gave $\mathbf{2} \mathbf{j}$ in only $26 \%$ yield. When carrying out the reaction with 2,6 disubstituted pyridine $\mathbf{1 k}$, we were pleased to observe that the oxidation process occurred too leading to benzil $\mathbf{2 k}$ in a good yield (57\% for the two triple bonds, entry 11). As expected, the presence of a quinoline moiety on the triple bond did not impact the outcome of the oxidation reaction and gave benzil $\mathbf{2 l}$ in $90 \%$ yield (entry 12), while a much lower yield was obtained when using $\mathrm{PdCl}_{2}$ instead of $\mathrm{PdI}_{2}$ 
(45\% not shown in Table). Finally, aliphatic arylalkyne $\mathbf{1 m}$ was also effective for the reaction and its oxidation provided the enolizable adduct 1,2-diketone $\mathbf{2 m}$ in a $58 \%$ non optimized isolated yield (entry 13).

Being given the high efficiency of this oxidation reaction, we expected that the newly developed procedure would serve as an extremely useful and quick synthetic route to obtain nitrogen-containing heterocyclic including quinoxaline and imidazole derivatives. These classes of substituted heterocyclic compounds offer a high degree of structural diversity and have proven to be broadly useful as biologically active compounds. In this context, we were interested to investigate the construction of these heterocyclic skeletons in a one-pot procedure as it would be economically and environmentally advantageous over multi-step syntheses.

Initially, the reagents and catalyst are mixed together and experimental conditions are set up in such a way to promote the reaction cascade. Typically, the reaction was carried out by heating at $140{ }^{\circ} \mathrm{C}$ diphenylalkyne 1n with $\mathrm{PdI}_{2}$ (2 mol\%) in DMSO in the presence of 1,2phenylenediamine (2 eq). Unfortunately, under these conditions, no significant formation of the desired quinoxaline 3a was observed, even after prolonged stirring, owing to probable nitrogen-oxidation side reactions. We then decided to achieve this transformation in a sequential way by heating in DMSO in a first step, 1n with $\mathrm{PdI}_{2}(2$ mol\%) then, by introducing 1,2-phenylenediamine (2 eq) in a second step. Thus under the protocol described above, we were pleased to observe that the tandem sequence worked very well and provided the desired quinoxaline $\mathbf{3 a}$ in $82 \%$ yield. The results summarized in Table 3 show that this tandem oxidation-nitrogen nucleophiles condensationcyclization was highly effective with a variety of diarylalkynes and nitrogen-nucleophiles reagents including anilines, $\mathrm{NH}_{4} \mathrm{OH}$, urea... Thus, quinoxalines $\mathbf{3 b}$-e variously substituted (Me, OMe, $\mathrm{CN}$ ) were synthesized according to the procedure described above in good yields ranging from $77 \%$ (entry 3) to $97 \%$ (entry 5). Moreover, this protocol is also convenient as it opens up an easy access to substituted imidazoles. As expected (entry 6), imidazole $3 \mathbf{f}$ was obtained in an excellent $96 \%$ yield from alkyne 1n (1 eq), 4-nitrobenzaldehyde (1 eq) and $\mathrm{NH}_{4} \mathrm{OH}$ (10 eq). Interestingly, when alkyne 1p was heated in DMSO in the presence of $\mathrm{PdI}_{2}$, the corresponding 1,2-diketone which upon refluxing with urea or thiourea cyclized to form in good yields the imidazolidin-2,4-dione $\mathbf{3 g}$ and thioxoimidazolidin-2,4-dione $\mathbf{3 h}$ respectively (entries 7 and 8). Altogether, these results demonstrated the efficiency of this tandem oxidation-nitrogen nucleophiles condensationcyclization to provide in a one-pot way a broad variety of nitrogen containing heterocycles of biological interest.

Finally, starting from the alkyne 1q the newly developed one-pot procedure have been successfully used for the synthesis of the thioxoimidazolidin-2,4-dione $\mathbf{3 i}$ in a satisfactory yield. The latter may be regarded as an analogue of the naturally combretastatin A-4 (CA-4), wellknown to act as both antimitotic and as a selective inhibitor of tumor vasculature growth. Compound $\mathbf{3 i}$ was evaluated for cytoxicity in human colon cancer HCT116 cells and was compared in contemporaneous experiment to the CA4. Unfortunately, the newly synthesized compound was significantly 100 -fold less potent $\left(\mathrm{IC}_{50}=600 \mathrm{nM}\right)$ in the growth inhibition assay in HCT116 cells than CA-4 $\left(\mathrm{IC}_{50}=\right.$ $2 \mathrm{nM}$ ) and was no further studied.

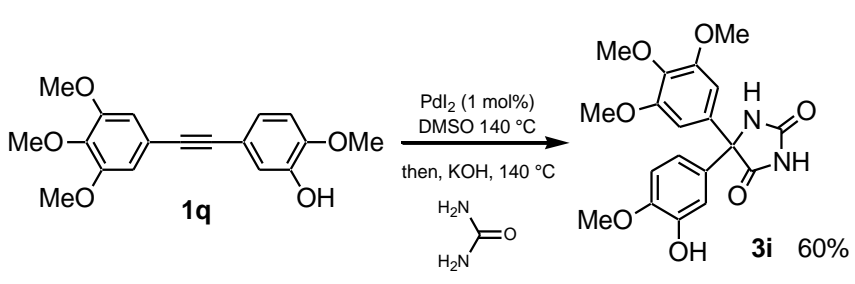

\section{Conclusion}

In summary, we successfully described a simple, rapid and high yielding synthesis of functionalized benzils from diarylalkynes using the couple $\mathrm{PdI}_{2} / \mathrm{DMSO}$. The chemoselectivity of this procedure, which requires low loading of catalyst, must be underlined as different substituents on the aromatic rings were tolerated as well as nitrogen-containing heterocycles nucleus. More interestingly, the procedure can be extended to the one-pot preparation of various heterocyclic compounds (quinoxalines, imidazoles, imidazolidine-2,4-diones...) based on a tandem oxidation-nitrogen nucleophiles condensation-cyclization. Variation is allowed in each of the partners, thus making a wide range of accessible heterocycles. This process is not only of interest for combinatorial synthesis of heterocycles, but in many cases, also offers considerable synthetic advantages in term of yield, selectivity, and simplicity of the reaction procedure.

\section{Experimental}

\subsection{Instrumentation}

The compounds were all identified by usual physical methods, i.e. ${ }^{1} \mathrm{H}-\mathrm{NMR},{ }^{13} \mathrm{C}-\mathrm{NMR}$, IR and elemental analysis. ${ }^{1} \mathrm{H}$ and ${ }^{13} \mathrm{C}$ NMR spectra were measured in $\mathrm{CDCl}_{3}$ with a Bruker Avance $300(300 \mathrm{MHz}) .{ }^{1} \mathrm{H}$ chemical shifts are reported in ppm from an internal standard TMS or of residual chloroform (7.27 ppm). The following abreviation are used: $m$ (multiplet), s (singlet), d (doublet), t (triplet), $\mathrm{dd}$ (doublet of doublet). ${ }^{13} \mathrm{C}$ chemical shifts are reported in ppm from the central peak of deuteriochloroform (77.14). IR spectra were measured on a Bruker Vector 22 spectrophotometer (neat, $\mathrm{cm}^{-1}$ ). Mass spectra were obtained with a Esquire LC Bruker spectrometer. Analytical TLC were performed on Merck precoated silica gel 60F plates. Merck silica gel 60 (230-400 mesh) was used for column 
chromatography. Melting points (m.p.) were recorded on a Büchi B-450 apparatus and were uncorrected.

\subsection{General procedure for the preparation of benzils 2a-p from alkynes}

A mixture of alkyne $1(1 \mathrm{mmol})$ and $\mathrm{PdI}_{2}(7.2 \mathrm{mg} ; 0.02$ mmol) in $7 \mathrm{~mL}$ of DMSO was stirred at $140^{\circ} \mathrm{C}$ for an appropriate time (see Table 2). After cooling to room temperature, $\mathrm{H}_{2} \mathrm{O}(15 \mathrm{~mL})$ was added and the mixture was extracted with EtOAc (3 x $15 \mathrm{~mL}$ ). Organic layers were then washed with an aqueous saturated $\mathrm{NH}_{4} \mathrm{Cl}$ solution, dried and concentrated. The crude mixture was then purified by column chromatography on silica gel to give benzil compounds 2 .

1-(4-Methoxyphenyl)-2-(4-cyanophenyl)ethane-1,2-

dione 2a: Yield: 91\%. Yellow solid, m.p.: 164-166 ${ }^{\circ} \mathrm{C}$. TLC: $\mathrm{R}_{\mathrm{f}} 0.81\left(\mathrm{CH}_{2} \mathrm{Cl}_{2}, \mathrm{SiO}_{2}\right)$. IR (neat) $v_{\max } / \mathrm{cm}^{-1}: 2940$, 2229, 1674, 1650, 1597, 1570, 1510, 1427, 1408, 1312, 1267, 1213, 1166, 1048, 1028, 884, 841, 781, 745. ${ }^{1} \mathrm{H}$ NMR $\left(\mathrm{CDCl}_{3}, 300 \mathrm{MHz}, 298 \mathrm{~K}\right): \delta 8.09(\mathrm{~d}, 2 \mathrm{H}, J=8.7$ $\mathrm{Hz}), 7.95(\mathrm{~d}, 2 \mathrm{H}, J=9.0 \mathrm{~Hz}), 7.80(\mathrm{~d}, 2 \mathrm{H}, J=8.7 \mathrm{~Hz}), 7.00$ $(\mathrm{d}, 2 \mathrm{H}, J=9.0 \mathrm{~Hz}), 3.91(\mathrm{~s}, 3 \mathrm{H}) .{ }^{13} \mathrm{C} \mathrm{NMR}\left(\mathrm{CDCl}_{3}, 75\right.$ $\mathrm{MHz}, 298 \mathrm{~K}): \delta 192.6(\mathrm{C}), 191.4(\mathrm{C}=\mathrm{O}), 165.4(\mathrm{C}=\mathrm{O})$, $136.1(\mathrm{C}), 132.6(2 \mathrm{CH}), 132.5(2 \mathrm{CH}), 130.2(2 \mathrm{C}), 125.5$ (C), $117.6(2 \mathrm{C}), 114.5(2 \mathrm{CH}), 55.7\left(\mathrm{OCH}_{3}\right)$. MS (APCI): $\mathrm{m} / \mathrm{z}, 266(\mathrm{M}+\mathrm{H})^{+}$.

Ethyl 4-(2-oxo-2-phenylacetyl)benzoate 2b: Yield: $96 \%$. Yellow solid, m.p.: $75-77 \quad{ }^{\circ} \mathrm{C}$. $\quad$ TLC: $\mathrm{R}_{\mathrm{f}} 0.48$ (Cyclohexane/EtOAc, 60/ 40, $\mathrm{SiO}_{2}$ ). IR (neat) $v_{\max } / \mathrm{cm}^{-1}$ : 1719, 1670, 1596, 1580, 1503, 1450, 1408, 1368, 1273, 1206, 1177, 1105, 1018, 887, 847, 782, 734, 711. ${ }^{1} \mathrm{H}$ NMR $\left(\mathrm{CDCl}_{3}, 300 \mathrm{MHz}, 298 \mathrm{~K}\right): \delta 8.15(\mathrm{~d}, 1 \mathrm{H}, J=8.4 \mathrm{~Hz}), 8.02$ $(\mathrm{d}, 2 \mathrm{H}, J=8.4 \mathrm{~Hz}), 7.96(\mathrm{~d}, 2 \mathrm{H}, J=7.5 \mathrm{~Hz}), 7.66(\mathrm{t}, 1 \mathrm{H}, J$ $=7.5 \mathrm{~Hz}), 7.51(\mathrm{t}, 2 \mathrm{H}, J=7.5 \mathrm{~Hz}), 4.40(\mathrm{q}, 2 \mathrm{H}, J=7.2 \mathrm{~Hz})$, $1.39(\mathrm{t}, 3 \mathrm{H}, J=7.2 \mathrm{~Hz}) .{ }^{13} \mathrm{C} \mathrm{NMR}\left(\mathrm{CDCl}_{3}, 75 \mathrm{MHz}, 298\right.$ $\mathrm{K}): \delta 193.8(\mathrm{CO}), 193.7$ (CO), $165.3(\mathrm{C}), 136.0(\mathrm{C}), 135.7$ $(\mathrm{CH}), 135.1(\mathrm{CH}), 132.7(\mathrm{C}), 130.0(2 \mathrm{CH}), 129.9(2 \mathrm{CH})$, $129.7(2 \mathrm{CH}), 129.1(2 \mathrm{CH}), 61.6\left(\mathrm{CH}_{2}\right), 14.2\left(\mathrm{CH}_{3}\right)$.

MS (APCI): $m / z 283(\mathrm{M}+\mathrm{H})^{+}$.

Ethyl 4-(2-oxo-2-phenylacetyl)benzaldehyde 2c: Yield: 93\%. Yellow solid, m.p.: 73-75 ${ }^{\circ} \mathrm{C}$. TLC: $\mathrm{R}_{\mathrm{f}} 0.35$ (Cyclohexane/EtOAc, 80/ 20, $\mathrm{SiO}_{2}$ ). IR (neat) $v_{\max } / \mathrm{cm}^{-1}$ : 1704, 1669, 1595, 1576, 1501, 1450, 1418, 1385, 1304, 1202, 1180, 1014, 881, 822, 791, 752, 719. ${ }^{1} \mathrm{H}$ NMR $\left(\mathrm{CDCl}_{3}, 300 \mathrm{MHz}, 298 \mathrm{~K}\right): \delta 10.11(\mathrm{~s}, 1 \mathrm{H}), 8.12(\mathrm{~d}, 2 \mathrm{H}, J=$ $8.4 \mathrm{~Hz}), 7.95-8.02(\mathrm{~m}, 4 \mathrm{H}), 7.67(\mathrm{tt}, 1 \mathrm{H}, J=7.2 \mathrm{~Hz}, J=1.2$ $\mathrm{Hz}), 7.52(\mathrm{~m}, 2 \mathrm{H}) .{ }^{13} \mathrm{C} \mathrm{NMR}\left(\mathrm{CDCl}_{3}, 75 \mathrm{MHz}, 298 \mathrm{~K}\right): \delta$ 193.5 (CO), 193.4 (CO), 191.2 (CHO), 139.9 (C), 136.9 (C), $135.2(\mathrm{CH}), 132.5(\mathrm{C}), 130.3(2 \mathrm{CH}), 130.0(2 \mathrm{CH})$, 129.9 (4CH), 129.1 (2CH). MS (APCI): $m / z 283(\mathrm{M}-\mathrm{H})^{-}$.

$\boldsymbol{N}$-(4-(2-oxo-2-ptolylacetyl)phenyl)acetamide 2f: Yield: 93\%. Yellow solid, m.p.: $123-125{ }^{\circ} \mathrm{C}$. TLC: $\mathrm{R}_{\mathrm{f}} 0.38$ (Cyclohexane/EtOAc, 60/ 40, $\mathrm{SiO}_{2}$ ). IR (neat) $v_{\max } / \mathrm{cm}^{-1}$ : 3323, 1671, 1589, 1526, 1410, 1371, 1318, 1265, 1220, 1169, 1121, 1017, 887, 851, 766, 745. ${ }^{1} \mathrm{H}$ NMR $\left(\mathrm{CDCl}_{3}\right.$, $300 \mathrm{MHz}, 298 \mathrm{~K}): \delta 8.22$ (s, 1H), 7.80-7.74 (m, 4H), 7.57 (d, 2H, $J=7.5 \mathrm{~Hz}), 7.21(\mathrm{~d}, 2 \mathrm{H}, J=7.8 \mathrm{~Hz}), 2.34(\mathrm{~s}, 3 \mathrm{H})$, $2.10(\mathrm{~s}, 3 \mathrm{H}) \cdot{ }^{13} \mathrm{C} \mathrm{NMR}\left(\mathrm{CDCl}_{3}, 75 \mathrm{MHz}, 298 \mathrm{~K}\right): \delta 194.7$ (CO), 193.7 (CO), 169.1 (NHCO), 146.4 (C), 144.1 (C), $131.3(2 \mathrm{CH}), 130.4(\mathrm{C}), 130.0(2 \mathrm{CH}), 129.7(2 \mathrm{CH}), 129.3$ (C), $119.2(2 \mathrm{CH}), 24.7\left(\mathrm{CH}_{3}\right), 21.9\left(\mathrm{CH}_{3}\right)$. MS (APCI): $\mathrm{m} / z$ $282(\mathrm{M}+\mathrm{H})^{+}$.

1-(2-Methoxyphenyl)-2-ptolylethane-1,2-dione 2h: Yield: 98\%. Yellow solid, m.p.: 98-101 ${ }^{\circ} \mathrm{C}$. TLC: $\mathrm{R}_{\mathrm{f}} 0.38$ (Cyclohexane/EtOAc, 80/ 20, $\mathrm{SiO}_{2}$ ). IR (neat) $v_{\max } / \mathrm{cm}^{-1}$ : 1660, 1599, 1485, 1466, 1438, 1266, 1203, 1178, 1161, 1114, 1018, 883, 831, 732, 703. ${ }^{1} \mathrm{H}$ NMR $\left(\mathrm{CDCl}_{3}, 300\right.$ $\mathrm{MHz}, 298 \mathrm{~K}): \delta 7.93(\mathrm{dd}, 1 \mathrm{H}, J=7.8 \mathrm{~Hz}, J=1.8 \mathrm{~Hz}), 7.73$ $(\mathrm{d}, 2 \mathrm{H}, J=8.4 \mathrm{~Hz}), 7.52-7.47(\mathrm{~m}, 1 \mathrm{H}), 7.20(\mathrm{~d}, 2 \mathrm{H}, J=8.4$ $\mathrm{Hz}), 7.05-7.00(\mathrm{~m}, 1 \mathrm{H}), 6.84(\mathrm{~d}, 1 \mathrm{H}, J=8.4 \mathrm{~Hz}), 3.48$ (s, $3 \mathrm{H}), 2.40(\mathrm{~s}, 3 \mathrm{H}) .{ }^{13} \mathrm{C} \mathrm{NMR}\left(\mathrm{CDCl}_{3}, 75 \mathrm{MHz}, 298 \mathrm{~K}\right): \delta$ 194.7 (CO), 193.3 (CO), 160.4 (C), 144.7 (C), 136.3 (CH), $130.5(\mathrm{CH}), 130.4(\mathrm{C}), 129.4(4 \mathrm{CH}), 123.9(\mathrm{C}), 121.4$ $(\mathrm{CH}), 112.3(\mathrm{CH}), 55.6\left(\mathrm{CH}_{3}\right), 21.8\left(\mathrm{CH}_{3}\right) . \mathrm{MS}(\mathrm{ESI}): \mathrm{m} / \mathrm{z}$ $277(\mathrm{M}+\mathrm{Na})^{+}$.

1,4-Bis(phenylglyoxalyl)benzene 2i: Yield: $90 \%$. Yellow solid, m.p.: $124-125^{\circ} \mathrm{C}$. TLC: $\mathrm{R}_{\mathrm{f}} 0.19$ (Cyclohexane/ $\mathrm{CH}_{2} \mathrm{Cl}_{2}, 80 / 20, \mathrm{SiO}_{2}$ ). IR (neat) $v_{\max } / \mathrm{cm}^{-1}$ : 1665, 1596, 1582, 1502, 1449, 1406, 1307, 1203, 1181, 1000, 936, 880, 831, 790, 725, 710. ${ }^{1} \mathrm{H}$ NMR $\left(\mathrm{CDCl}_{3}, 300 \mathrm{MHz}, 298 \mathrm{~K}\right): \delta$ $8.10(\mathrm{~s}, 4 \mathrm{H}), 7.96(\mathrm{~d}, 4 \mathrm{H}, J=7.5 \mathrm{~Hz}), 7.68(\mathrm{t}, 2 \mathrm{H}, J=7.5$ $\mathrm{Hz}), 7.52(\mathrm{t}, 4 \mathrm{H}, J=7.8 \mathrm{~Hz}) \cdot{ }^{13} \mathrm{C} \mathrm{NMR}\left(\mathrm{CDCl}_{3}, 75 \mathrm{MHz}\right.$, $298 \mathrm{~K}): \delta 193.3$ (2CO), 193.2 (2CO), 137.0 (2C), 135.2 (2C), $132.4(2 \mathrm{CH}), 130.2(4 \mathrm{CH}), 130.9(4 \mathrm{CH}), 129.1$ (4CH). MS (ESI): $m / z, 343(\mathrm{M}+\mathrm{H})^{+}$.

1-(4-Methoxyphenyl)-2-(pyridine-2-yl)ethane-1,2-dione 2j: Yield: $62 \%$. Brown solid, m.p.: 97-98 ${ }^{\circ} \mathrm{C}$. TLC: $\mathrm{R}_{\mathrm{f}} 0.22$ (Cyclohexane/EtOAc, 70/ 30, $\mathrm{SiO}_{2}$ ). IR (neat) $v_{\max } / \mathrm{cm}^{-1}$ : 1696, 1666, 1597, 1575, 1511, 1464, 1440, 1424, 1312, $1258,1225,1169,1113,1060,1022,995,890,843,812$, 795, 746. ${ }^{1} \mathrm{H} \mathrm{NMR}\left(\mathrm{CDCl}_{3}, 300 \mathrm{MHz}, 298 \mathrm{~K}\right): \delta 8.63(\mathrm{~d}$, $1 \mathrm{H}, J=4.5 \mathrm{~Hz}), 8.15(\mathrm{~d}, 1 \mathrm{H}, J=7.8 \mathrm{~Hz}), 7.92-7.88(\mathrm{~m}$, $3 \mathrm{H}), 7.50-7.46(\mathrm{~m}, 1 \mathrm{H}), 6.87(\mathrm{~d}, 2 \mathrm{H}, J=9 \mathrm{~Hz}), 3.90(\mathrm{~s}$, $3 \mathrm{H}) .{ }^{13} \mathrm{C} \mathrm{NMR}\left(\mathrm{CDCl}_{3}, 75 \mathrm{MHz}, 298 \mathrm{~K}\right): \delta 195.4(\mathrm{CO})$, 194.6 (CO), $164.5(\mathrm{C}), 151.9(\mathrm{C}), 149.9(\mathrm{CH}), 137.4(\mathrm{CH})$, $132.1(2 \mathrm{CH}), 128.1(\mathrm{CH}), 126.4(\mathrm{C}), 123.3(\mathrm{CH}), 114.4$ $(2 \mathrm{CH}), 55.7\left(\mathrm{CH}_{3}\right)$. MS (ESI): $m / z 242(\mathrm{M}+\mathrm{H})^{+}$.

1-phenyl-2-(quinolin-3-yl)ethane-1,2-dione 2l: Yield: $90 \%$. Yellow solid, m.p.: $127-129{ }^{\circ} \mathrm{C}$. TLC: $\mathrm{R}_{\mathrm{f}} 0.33$ (Cyclohexane/EtOAc, 80/ 20, $\mathrm{SiO}_{2}$ ). IR (neat) $v_{\max } / \mathrm{cm}^{-1}$ : $1665,1616,1594,1570,1495,1450,1420,1374,1319$, 1298, 1259, 1209, 1172, 1127, 1000, 974, 926, 894, 840, 787, 760, 744, 716. ${ }^{1} \mathrm{H}$ NMR $\left(\mathrm{CDCl}_{3}, 300 \mathrm{MHz}, 298 \mathrm{~K}\right): \delta$ $9.47(\mathrm{~s}, 1 \mathrm{H}), 8.71(\mathrm{~d}, 1 \mathrm{H}, J=2.1 \mathrm{~Hz}), 8.16(\mathrm{~d}, 1 \mathrm{H}, J=8.4$ $\mathrm{Hz})$, 8.04-8.01 (m, 2H), 7.90-7.82 (m, 2H), 7.70-7.59 (m, 2H), 7.55-7.49 (m, 2H). ${ }^{13} \mathrm{C} \mathrm{NMR}\left(\mathrm{CDCl}_{3}, 75 \mathrm{MHz}, 298\right.$ $\mathrm{K}): \delta 193.0(\mathrm{CO}), 192.7$ (CO), $150.3(\mathrm{C}), 149.1$ (C), 140.1 $(\mathrm{CH}), 135.2(\mathrm{CH}), 133.0(\mathrm{CH}), 132.5(\mathrm{C}), 130.1(2 \mathrm{CH})$, $129.6(2 \mathrm{CH}), 129.5(2 \mathrm{CH}), 127.9(\mathrm{CH}), 126.4(\mathrm{C}), 125.3$ (C). MS (ESI): $m / z, 262(\mathrm{M}+\mathrm{H})^{+}$. 
General procedure for the preparation of quinoxalines 3a-e from alkynes 1.

Following the procedure described for benzils 2, and after cooling, a DMSO solution, of the arylenediamine $(2 \mathrm{mmol}$, 2 eq) was added to the mixture and heated at $140{ }^{\circ} \mathrm{C}$ for the appropriate reaction time (see Table 3 ). After cooling to room temperature, $\mathrm{H}_{2} \mathrm{O}(15 \mathrm{~mL})$ was added, and the mixture was extracted with EtOAc $(3 \times 15 \mathrm{~mL})$. Organic layers were then washed with an aqueous saturated $\mathrm{NH}_{4} \mathrm{Cl}$ solution, dried and concentrated. The crude mixture was then purified by column chromatography on silica gel to give quinoxalines 3a-e

2,3-Diphenylquinoxaline $3 \mathbf{a}^{16}$ (Yield: $82 \%$ ) and 6-methyl2,3-diphenylquinoxaline $\mathbf{3 d}^{17}$ (Yield: 88\%) which are known compounds gave satisfactory data.

2-(4-methoxyphenyl)-3-phenylquinoxaline 3b: Yield: $80 \%$. Orange oil. TLC: $\mathrm{R}_{\mathrm{f}} 0.57\left(\mathrm{CH}_{2} \mathrm{Cl}_{2}, 70 / 30, \mathrm{SiO}_{2}\right)$. IR (neat) $v_{\max } / \mathrm{cm}^{-1}: 3062,2934,2837,2226,1606,1578$, $1558,1537,1513,1477,1463,1444,1418,1394,1344$, $1293,1222,1175,1142,1128,1112,1077,1058,1025$, 978, 907, 837, 808, 785, 761, 727. ${ }^{1} \mathrm{H}$ NMR $\left(\mathrm{CDCl}_{3}, 300\right.$ $\mathrm{MHz}, 298 \mathrm{~K}): \delta$ 8.30-8.17 (m, 2H), 7.76-7.70 (m, 2H), 7.57-7.54 (m, 2H), 7.49 (d, $2 \mathrm{H}, J=8.8 \mathrm{~Hz}), 7.37-7.35(\mathrm{~m}$, $2 \mathrm{H}), 6.83(\mathrm{~d}, 2 \mathrm{H}, J=8.8 \mathrm{~Hz}), 3.81(\mathrm{~s}, 3 \mathrm{H}) .{ }^{13} \mathrm{C} \mathrm{NMR}$ $\left(\mathrm{CDCl}_{3}, 75 \mathrm{MHz}, 298 \mathrm{~K}\right): \delta 160.1$ (C), 153.3 (C), 152.9 (C), 141.2 (C), 140.9 (C), 139.3 (2C), 131.3 (2CH), 129.7 $(\mathrm{CH}), 129.6(2 \mathrm{CH}), 129.5(\mathrm{CH}), 129.1(\mathrm{CH}), 129.0(\mathrm{CH})$, $128.6(\mathrm{CH}), 128.2(2 \mathrm{CH}), 113.6(2 \mathrm{CH}), 55.2\left(\mathrm{CH}_{3}\right) . \mathrm{MS}$ (APCI): $m / z 313(\mathrm{M}+\mathrm{H})^{+}$.

\section{2-(4-Methoxyphenyl)-6,7-dimethyl-3-phenylquinoxaline} 3c: Yield: $80 \%$. brown oil. TLC: $\mathrm{R}_{\mathrm{f}} 0.21$ (Cyclohexane/ EtOAc, 90/ 10, $\mathrm{SiO}_{2}$ ). IR (neat) $v_{\max } / \mathrm{cm}^{-1}$ : 1606, 1578, 1514, 1481, 1461, 1416, 1398, 1344, 1296, 1249, 1208, 1174, 1110, 1061, 1026, 972, 909, 870, 837, 810, 776, 758. ${ }^{1} \mathrm{H}$ NMR $\left(\mathrm{CDCl}_{3}, 300 \mathrm{MHz}, 298 \mathrm{~K}\right): \delta 7.85(\mathrm{~s}, 2 \mathrm{H}), 7.53-$ $7.46(\mathrm{~m}, 2 \mathrm{H}), 7.45$ (d, 2H, $J=8.8 \mathrm{~Hz}), 7.36-7.33(\mathrm{~m}, 3 \mathrm{H})$, $6.81(\mathrm{~d}, 2 \mathrm{H}, J=8.8 \mathrm{~Hz}), 3.81(\mathrm{~s}, 3 \mathrm{H}), 2.50(\mathrm{~s}, 6 \mathrm{H}),{ }^{13} \mathrm{C}$ NMR $\left(\mathrm{CDCl}_{3}, 75 \mathrm{MHz}, 298 \mathrm{~K}\right): \delta 159.9$ (C), $152.4(\mathrm{C})$, 152.0 (C), 140.3 (C), 140.2 (C), 140.1 (C), 139.9 (C), 139.6 (C), $131.7(\mathrm{C}), 131.2(2 \mathrm{CH}), 129.7(2 \mathrm{CH}), 128.4(\mathrm{CH})$, $128.2(2 \mathrm{CH}), 128.1(\mathrm{CH}), 128.0(\mathrm{CH}), 113.6(2 \mathrm{CH}), 55.2$ $\left(\mathrm{CH}_{3}\right), 20.4\left(2 \mathrm{CH}_{3}\right)$. MS (APCI): $m / z 341(\mathrm{M}+\mathrm{H})^{+}$.

4-(3-Phenyl-quinoxalin-2-yl)benzonitrile $3 \mathbf{e}$ : Yield: 97\%. Yellow solid, m.p.: $168-170^{\circ} \mathrm{C}$. TLC: $\mathrm{R}_{\mathrm{f}} 0.49$ (Cyclohexane/EtOAc, 70/ 30, $\mathrm{SiO}_{2}$ ). IR (neat) $v_{\max } / \mathrm{cm}^{-1}$ : 2225, 1477, 1342, 1057, 1022, 976, 844, 813, 775, 723. ${ }^{1} \mathrm{H}$ NMR $\left(\mathrm{CDCl}_{3}, 300 \mathrm{MHz}, 298 \mathrm{~K}\right): \delta 8.12(\mathrm{~m}, 2 \mathrm{H}), 7.75(\mathrm{~m}$, $2 \mathrm{H}), 7.65-7.50(\mathrm{~m}, 4 \mathrm{H}), 7.50-7.28(\mathrm{~m}, 5 \mathrm{H}) .{ }^{13} \mathrm{C} \quad \mathrm{NMR}$ $\left(\mathrm{CDCl}_{3}, 75 \mathrm{MHz}, 298 \mathrm{~K}\right): \delta 153.1(\mathrm{C}), 151.3(\mathrm{C}), 143.6$ (C), 141.5 (C), 141.1 (C), 138.3 (C), 132.1 (2CH), 130.8 $(\mathrm{CH}), 130.6(2 \mathrm{CH}), 130.5(\mathrm{CH}), 129.8(2 \mathrm{CH}), 129.3$ $(3 \mathrm{CH}), 128.6(2 \mathrm{CH}), 118.6(\mathrm{C}), 112.5(\mathrm{CN})$.

MS (APCI): $m / z 308(\mathrm{M}+\mathrm{H})^{+}$.

Synthesis of 2-(4-nitrophenyl)diphenylimidazole 3f: Following the procedure described for benzils $\mathbf{2}$, and after cooling, an $\mathrm{AcOH}(25 \mathrm{~mL})$ solution of $\mathrm{NH}_{4} \mathrm{OAc}(10 \mathrm{mmol}$, $10 \mathrm{eq}, 0.77 \mathrm{~g})$ and 4-nitrobenzaldehyde (1.2 mmol, $0.18 \mathrm{~g}$ ) were added to the mixture and heated at $140{ }^{\circ} \mathrm{C}$ for $12 \mathrm{~h}$. After cooling, the crude was concentrated and extracted with $\mathrm{CH}_{2} \mathrm{Cl}_{2}(3 \times 15 \mathrm{~mL})$. Organic layers were then washed with an aqueous saturated $\mathrm{NH}_{4} \mathrm{Cl}$ solution, dried and concentrated. The crude mixture was then purified by column chromatography on silica gel to give 3f (Yield: $96 \%$ ). Spectral data of $\mathbf{3 f}$ were identical to those previously reported. $^{18}$

Synthesis of compounds 3g-i: Following the procedure described for benzils 2 , and after cooling, a solution of urea or thiourea (2 mmol, $2 \mathrm{eq}$ ) and $\mathrm{KOH}(3 \mathrm{~mL} ; 1.2 \mathrm{M})$ were added to the mixture and heated at $140{ }^{\circ} \mathrm{C}$ for the appropriate reaction time (see Table 3 ). After cooling, $\mathrm{H}_{2} \mathrm{O}$ $(15 \mathrm{~mL})$ was added, and the mixture was extracted with EtOAc (3 x $15 \mathrm{~mL})$. Organic layers were then washed with an aqueous saturated $\mathrm{NH}_{4} \mathrm{Cl}$ solution, dried and concentrated. The crude mixture was then purified by column chromatography on silica gel to give $\mathbf{3 g - i}$.

5-(4-methoxyphenyl)-5-ptolylimidazolidine-2,4-dione 3g: Yield: $90 \%$. Yellow solid, m.p.: $214-218{ }^{\circ} \mathrm{C}$. TLC: $\mathrm{R}_{\mathrm{f}} 0.35$ (Cyclohexane/EtOAc, 60/ 40, $\mathrm{SiO}_{2}$ ). IR (neat) $v_{\max } / \mathrm{cm}^{-1}$ : 3193, 2359, 1776, 1698, 1608, 1508, 1420, 1299, 1251, 1175, 1119, 1035, 973, 926, 757, 718. ${ }^{1} \mathrm{H} \quad \mathrm{NMR}$ $\left(\mathrm{CD}_{3} \mathrm{COCD}_{3}, 300 \mathrm{MHz}, 298 \mathrm{~K}\right): \delta 9.96(\mathrm{~s}, 1 \mathrm{H}), 8.22(\mathrm{~s}$, $1 \mathrm{H}), 7.39(\mathrm{~d}, 2 \mathrm{H}, J=9.0 \mathrm{~Hz}), 7.36(\mathrm{~d}, 2 \mathrm{H}, J=9.0 \mathrm{~Hz}), 7.22$ $(\mathrm{d}, 2 \mathrm{H}, J=9.0 \mathrm{~Hz}), 6.96(\mathrm{~d}, 2 \mathrm{H}, J=9.0 \mathrm{~Hz}), 3.81(\mathrm{~s}, 3 \mathrm{H})$, $2.34(\mathrm{~s}, 3 \mathrm{H}) .{ }^{13} \mathrm{C} \mathrm{NMR}\left(\mathrm{CD}_{3} \mathrm{COCD}_{3}, 75 \mathrm{MHz}, 298 \mathrm{~K}\right): \delta$ 175.6 (CO), $160.4(\mathrm{C}), 156.6(\mathrm{CO}), 138.6$ (C), 138.4 (C), $133.1(\mathrm{C}), 129.9(2 \mathrm{CH}), 129.0(2 \mathrm{CH}), 127.7(2 \mathrm{CH}), 114.6$ $(2 \mathrm{CH}), 71.4(\mathrm{C}), 55.6\left(\mathrm{OCH}_{3}\right), 21.0\left(\mathrm{CH}_{3}\right) . \mathrm{MS}(\mathrm{ESI}): \mathrm{m} / z$ $319(\mathrm{M}+\mathrm{Na})^{+}$.

5-(3-hydroxy-4-methoxyphenyl)-5-(3,4,5trimethoxyphenyl)imidazolidine-2,4-dione 3h: Yield: $60 \%$. White solid, m.p.: $240^{\circ}$ C. TLC: $\mathrm{R}_{\mathrm{f}} 0.35$ (Cyclohexane/EtOAc, 60/ 40, $\mathrm{SiO}_{2}$ ). IR (neat) $v_{\max } / \mathrm{cm}^{-1}: 3377,3224,2937,1769,1716$, 1591,1509 , 1462, 1414, 1399, 1333, 1272, 1227, 1129, 1104, 1016, 1003, 859, 823, 810, 754, 735, 686, . ${ }^{1} \mathrm{H}$ NMR $\left(\mathrm{CD}_{3} \mathrm{COCD}_{3}, 300 \mathrm{MHz}, 298 \mathrm{~K}\right): \delta 9.70(\mathrm{~s}, 1 \mathrm{H}), 8.05(\mathrm{~s}$, $1 \mathrm{H}), 7.55(\mathrm{~s}, 1 \mathrm{H}), 6.80-6.68(\mathrm{~m}, 5 \mathrm{H}), 3.70(\mathrm{~s}, 3 \mathrm{H}), 3.64(\mathrm{~s}$, $6 \mathrm{H}), 3.60(\mathrm{~s}, 3 \mathrm{H}) .{ }^{13} \mathrm{C} \mathrm{NMR}\left(\mathrm{CD}_{3} \mathrm{COCD}_{3}, 75 \mathrm{MHz}, 298 \mathrm{~K}\right)$ :

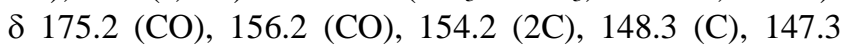
(C), $136.3(2 \mathrm{C}), 134.2(\mathrm{C}), 118.7(\mathrm{CH}), 114.9(\mathrm{CH}), 112.1$ $(\mathrm{CH}), 105.6(2 \mathrm{CH}), 71.3(\mathrm{C}), 60.5\left(\mathrm{OCH}_{3}\right), 56.5\left(2 \mathrm{OCH}_{3}\right)$, $56.2\left(\mathrm{OCH}_{3}\right)$. MS (ESI): $m / z, 319(\mathrm{M}+\mathrm{Na})^{+}$.

5-(4-methoxyphenyl)-2-thioxo-5-ptolylimidazolidin-4one 3i: Yield: $88 \%$. Orange oil. TLC: $R_{f} 0.28$ (Cyclohexane/EtOAc, 60/ 40, $\mathrm{SiO}_{2}$ ). IR (neat) $v_{\max } / \mathrm{cm}^{-1}$ : 3196, 1721, 1692, 1608, 1508, 1389, 1301, 1248, 1163, $1121,1028,928,816,735 .{ }^{1} \mathrm{H}$ NMR $\left(\mathrm{CD}_{3} \mathrm{COCD}_{3}, 300\right.$ $\mathrm{MHz}, 298 \mathrm{~K}$ ): $\delta 10.59$ (s, 1H), 9.75 (s, 1H), 7.09 (d, 2H, J= $8.9 \mathrm{~Hz}), 7.06(\mathrm{~d}, 2 \mathrm{H}, J=8.4 \mathrm{~Hz}), 6.98(\mathrm{~d}, 2 \mathrm{H}, J=8.4 \mathrm{~Hz})$, $6.72(\mathrm{~d}, 2 \mathrm{H}, J=8.9 \mathrm{~Hz}), 3.55(\mathrm{~s}, 3 \mathrm{H}), 2.08(\mathrm{~s}, 3 \mathrm{H}) .{ }^{13} \mathrm{C}$ NMR $\left(\mathrm{CD}_{3} \mathrm{COCD}_{3}, 75 \mathrm{MHz}, 298 \mathrm{~K}\right): \delta 182.2$ (CS), 175.9 (CO), 160.6 (C), 139.1 (C), 136.8 (C), 131.5 (C), 130.0 
(2CH), $129.0(2 \mathrm{CH}), 127.6(2 \mathrm{CH}), 114.8(2 \mathrm{CH}), 74.1(\mathrm{C})$, $55.6\left(\mathrm{OCH}_{3}\right), 21.0\left(\mathrm{CH}_{3}\right)$. MS (ESI): $\mathrm{m} / z 312.8(\mathrm{M}+\mathrm{H})^{+}$.

\section{Acknowledgments}

The CNRS is gratefully acknowledged for support of this research. Thanks also to the MNSER for a doctoral fellowship to C.M.

\section{References}

1 (a) Sonogashira, K.; Tokai, Y.; Hagihara, N. Tetrahedron Lett., 1975, 4467. (b) Alami, M.; Ferri, F.; Linstrumelle, G. Tetrahedron Lett. 1993, 34, 1433. (c) Alami, M.; Ferri, F.; Gaslain, Y. Tetrahedron Lett. 1996, 37, 57-58

2 Katriszky, A. R.; Zhang, D.; Kirichenko, K. J. Org. Chem. 2005, 70, 3271 and references therein.

3 (a) Vollhardt, K. P. C.; Schore, N. E. Organic chemistry, $2^{\text {nd }}$ ed.; New York, 1994, 924. (b) Hillis, L. R.; Ronald, R. C. J. Org. Chem. 1985, 50, 470. (c) Rozwadowska, M. D.; Chrzanowska, M. Tetrahedron 1985, 41, 2885. (d) Re, L.; Maurer, B.; Ohloff, G.; Helv. Chim. Acta 1973, 56, 1882. (e) Vofsi, D.; Asscher, M. Org. Synth., Coll. Vol. V; Wiley: New York, 1973, 1076. (f) Cope, A. C.; Smith, D. S.; Cotter, R. J. Org Synth., Coll. Vol. IV; Wiley: New York, 1963, 377. (g) Morrison, H.; Danishefsky, S.; Yates, P. J. Org. Chem. 1961, 26, 2617. (h) Smith, L. I.; Hoehn, H. H. Org. Synth., Coll. Vol. III; Wiley: New York, 1955, 356. (i) Johnson, J.R.; Grummitt, O. Org. Synth., Coll. Vol. III; Wiley: New York, 1955, 806.

4 (a) Deng, X.; Mani, N. S. Org. Lett. 2006, 8, 269. (b) Lee, D.; Chang, V. S. Synthesis, 1978, 462.

5 Rogatchov, V. O., Filimonov, V. D.; Yusubov, M. S. Synthesis 2001, 1001

6 Gebeyehu, G.; McNelis, E. J. Org. Chem. 1980, 45, 4280.

$7 \quad$ Li, P.; Cheong, F. H.; Chao, L. C. F.; Lin, Y. H.; Williams, I. D. J. Mol. Catal. A 1999, 145, 111.

8 Sheu, C.; Richert, S. A.; Cofré, P.; Ross, Jr. B.; Sobkowiak, A.; Sawyer, D. T.; Kanofsky, J. R. J. Am. Chem. Soc. 1990, 112, 1936.

9 Wan, Z.; Jones, C.D.; Mitchell, D.; Pu, J.Y.; Zhang, T.Y. J. Org. Chem. 2006, 71, 826.

10 Yusubov, M. S.; Zholobova, G. A.; Vasilevsky, S. F.; Tretyakov, E. V.; Knight, D. W. Tetrahedron 2002, 58, 1607.

11 Chi, K. W.; Yusubov, M. S.; Filimonov, V. D. Synth. Commun. 1994, 24, 2119.

12 (a) Magnus, P.; Stent, M. Org. Lett. 2005, 7, 3853. (b) Yusubov, M.S.; Krasnokutskaya, E.A.; Vasilyeva,
Filimonov, V.D.; Chi, K.W. Bull. Korean Chem. Soc. 1995, 16, 86.

13 Kim, H.G.; Lee, J.K.; Lee, J.T.; Lee, C.S. Bull. Korean Chem. Soc. 2000, 21, 345.

14 Giraud, A.; Provot, O.; Peyrat, J.F.; Alami, M.; Brion, J.D. Tetrahedron 2006, 62, 7667.

15 (a) Le Bras, G.; Peyrat, J.-F.; Brion, J.-D.; Alami, M.; Marsaud, V.; Radanyi, C.; Renoir, J.-M. J. Med. Chem. 2007, 50, 6189. (b) Audisio, D.; Messaoudi, S.; Peyrat, J.-F.; Brion, J.-D.; Alami, M. Tetrahedron Lett. 2007, 48, 6928. (c) Messaoudi, S.; Audisio, D.; Brion, J.-D.; Alami, M. Tetrahedron 2007, 63, 10202. (d) Provot, O.; Giraud, A.; Peyrat, J.-F.; Alami, M.; Brion, J.-D. Tetrahedron Lett. 2005, 46, 8547.

16 Darabantu, M.; Boully, L.; Turck, A.; Plé, N. Tetrahedron, 2005, 61, 2897.

17 Kaupp, G.; Naimi-Jamal, M. R. Eur. J. Org. Chem. 2002, 1368.

18 M. Kimura, M. Tsunenaga, S. Takami, Y. Ohbayashi Bull. Chem. Soc. Jpn. 2005, 78, 929. 